\section{LIMBAH BAHAN BERBAHAYA DAN BERACUN}

\section{Oleh : D. Karyadi}

\section{ABSTRACT}

The waste of $B_{3}$ is every waste contain of a dangerous and or toxic goods. aste can be producced from spesific source, not spesific source and disposal icals.

B3 waste has one or more characteristic as follow : corrosive reactive, easy $\mathrm{m}$, easy to explode, toxic and infection.

Every body or enterprice is not permitted to import $B_{3}$ waste from rd to Indonesia or vice versa without permission from the Goverment of esian Republic.

\section{INTISARI}

Limbah $B_{3}$ adalah setiap limbah yang mengandung bahan berbahaya dan beracun. Limbah $B_{3}$ dapat dihasilkan dari sumber spesific, sumber tidak fic dan bahan kimia yang dibuang.

Limbah B3 memiliki satu atau lebih karakteristik berikut ; korosif, remudah terbakar, mudah meledak beracun dan menyebabkan infeksi.

Setiap orang atau badan usaha dilarang memasukkan limbah $\mathrm{B}_{3}$ dari luar i ke dalam negeri atau sebaliknya tanpa persetujuan pemerintah Republik aesia.

\section{PENDAHULUAN}

Pada saat ini, masalah lingkungan hidup semakin gencar dibicarakan di , baik oleh kalangan negarawan, politisi, ilmuwan dan para pecinta alam, un masyarakat luas. Sebagian masyarakat dunia telah menyadari betapa ingnya kelestarian alam, sebab merupakan prasyarat kelangsungan hidup usia generasi mendatang yang terbatas pada tata ruang dan waktu.

Namun kita tidak dapat menyangkal bahwa pembangunan industri atau ologi memang penting, tetapi bukan berarti kelestarian lingkungan tidak perlu mendapat perhatian. Dengan tegas bagaimanapun pesatnya suatu pembangunan, maka lingkungan harus dipelihara, karena pada akhirnya pembangunan itu tidak ada artinya, kalau lingkungan hidup telah rusak.

Oleh karena lingkungan hidup adalah milik kita bersama, maka perlu kita jaga bersama. Keadaan lingkungan hidup tergantung kepada setiap anggota masyarakat dan tidak dapat kita serahkan hanya kepada pemerintah. Maka usaha pemeliharaan dan peiestariannya tidak akan pernah berhasil, jika diantara kita tidak mau ikut daa terlibat didalamnya.

Salah satu penyebab rusaknya lingkungan hidup adalah limbah industri yang tidak dilola dengan baik sehingga mencemari lingkungan sekitarnya. lang kah pertama yanng dilakukan dalam pengelolaan limbah adalah mengklasifikasikan limbah tersebut, termasuk limbah $\mathrm{B}_{3}$ atau tidak. Pengklasifikasian in akan memudahkan pihak penghasil (produsen), pengangkut atau pengolah dalam menangani limbah tersebut.

\section{LIMBAH BAHAN BERBAHAYA DAN BERACUN $\left(B_{3}\right)$}

\section{A. DEFINISI LIMBAH B3}

Limbah adalah bahan sisa suatu proses produksi dan atau bahan yang tidak dapat digunakan. Limbah B3 aadalah setiap limbah yang mengandung beracun, karena sifat dan konsentrasinya, baik secara langsung atau tidak langsung dapat merusak dan atau mencemarkan lingkungan hidup dan atau dapat membahayakan kehidupan manusia.

Limbah B3 dapat dihasilkan dari sumber spesifik, sumber tidak spesifik, bahan kimia yang dibuang (karena tidak memenuhi spesifikasi, kadaluarsa, tumpahan, sisa kemasan atau produksi yang gagal).

\section{B. KLASIFIKASI LIMBAH B3}

Limbah B3 memiliki satu atau lebih karakteristik berikut : korosif, reaktif, mudah terbakar, mudah meledak, beracun, dan menyebabkan infeksi. Pengklasifikasian limbah B3 berdasarkan karakteristiknya dapat dibagi menjadi 7 kategori seperti dijelaskan di bawah ini.

1. Limbah Mudah Meledak

Limbah yang melalui reaksi kimai dapat menghasilkan gas dengan suhui dan tekanan tinggi yang dengan cepat dapat merusak lingkungan sekitarnya.

Vol. X No. 20 Tahun 1994́/1995 


\section{Limbah Mudah Terbakat}

Limbah yang apabila berdekatan dengan api, percikan api, gesekan atau sumber nyala lain akan mudah menyala/terbakar dan apabila telah menyala akan terus terbakar hebat dalam waktu lama.

Limbah Yang Menyebabkaan Korosi

Limbah yang dapat menyebabkan iritasi (terbakar) pada kulit atau mengkorosikan baja. Limbah ini mempunyai $\mathrm{pH}$ sama atau kurang dari 2,0 un. tuk limbah yang bersifat asam dan sama atau lebih besar dari 12,5 untuk yang bersifat basa.

Limbah Yang Reaktir

Limbah yang menyebabkan kebakaran karena melepaskan oksigen atau limbah organik pereoksida yang tidak stabil dalam suhu tinggi.

Limbah Yang Menyebabkan Infeksi

Bagian tubuh manusia, cairan dari tubuh manusia yang terkena infeksi dan limbah dari laboratorium yang terinfeksi kuman penyakit yang dapat menular.

Limbah ini berbahaya karena mengandung kuman penyakit seperti hepatitis dan kolera yang ditularkan pada pekerja, pembersih jalan, dan masyarakat di sektiar lokasi pembuangan limbah.

\section{Limbah Beracun}

Limbah yang menyebabkan racun bagi manusia dan lingkungan dapat menyebabkan kematian atau sakit yang serius. Limbah ini dapat masuk kedalam tubuh melalui pernafasan, kulit, atau mulut. Uji LD 50 atau LC 50 dapat digunakan untuk identifikasi limbah ini.

\section{Limbah-limbah lain}

Limbah yang tidak memenuhi karakteristik seperti diatas tetapi dapat menyebabkan bahaya dan/atau racun bagi manusia dan lingkungan termasuk dalam kelompok ini. Limbah beracun ini tercuci dan masuk kedalam air tanah sehingga dapat mencemari sumur penduduk disekitarnya. Limbah ini biasanya disebut LEACHATETOXIC. Kriteria-kriteria lain dapat digunakan untuk menentukan sifat dan tingkat bahaya bagi manusia dan lingkungan seperti toksisitas kronik, toksisitas akuatik, bioakumulasi atau persistensinya di lingkungan.

Daftar limbah B3 dari : sumber yang tidak spesifik, sumber yang spesifik dan bahan kimia kadaluarsa, tumpahan, sisa kemasan atau buangan produk yang tidak memenuhi spesifikasi dapat dilihat pada lampiran 2,3 dan 4 .
C. LIMBAH B3 DARI SUMBER : SPESIFIK, TIDAK SPESIFIK DAN BAHAN KIMIA YANG DIBUANG, TUMPAHAN, SISA KEMASAN, BAHAN KIMIA KADALUWARSA ATAU PRODUKSI YANG GAGAL

a. Limbah B3 dari Sumber Spesifik

Sisa proses suatu industri atau kegiatan tertentu seperti tercantum pada daftar terlampir.

b. Limbah B3 dari Sumber Tidak Spesifik

Limbah yang berasal bukan dari proses utamanya tetapi berasal dari kegiatan pemeliharaan alat, pencucian, inhibitor korosi, pelarutan kerak, pengasaman, dan lain-lain.

c. Limbah B3 dari bahan kimia yang dibuang (tumpahan, sisa kemasan, bahan kimia kadaluwarsa atau produksi yang gagal). Oleh karena tidak memenuhi kriteria yang ditentukan atau tidak dapat dimanfaatkan kembali, maka suatu produk menjadi limbah B3 yang memerlukan pengelolaan seperti limbah B3 lainnya. Hal yang sama juga berlaku untuk sisa kemasan limbah B3 dan bahan-bahan kimia yang kadaluwarsa serta produksi yang gagal

\section{IDENTIFIKASI LIMBAH B3}

Tahap-tahap dalam mengidentifikasi limbah B3 :

- identifikasi limbah yang dihasilkan

- mencocokan dengan daftar limbah B3

- jika tidak termasuk kedalam daftar, periksa karakteristik limbah tersebut: mudah meledak, mudah terbakar, beracun, infeksi, korosif atau reaktif.

- jika tidak memiliki salah satu karakteristik diatas lakukan uji.

- pisahkan limbah B3 dari limbah lainnya Untuk lebih jelasnya dapat dilihat pada lampiran 1

\section{E. PENGAWASAN}

Setiap orang atau badan usaha dilarang memasarkan limbah $\mathrm{B}_{3}$ dari luar negeri ke dalam wilayah Negara Republik Indonesia.

Pengangkutan limbah $B_{3}$ dari luar negeri melalui wilayah Negara Republik Indonesia, wajib dilakukan dengan memberitahukan terlebih dahulu secara tertulis kepada Pemerintah Republik Indonesia.

Pengiriman limbah $B_{3}$ keiuar negeri dapat dilakukan setelah mendapat persetujuan tertulis dari pemerintah dari negara penerima dan mendapatkan izin tertulis dari Pemerintah Republik Indonesia.

Vol. X No. 20 Tahun 1994/1995 
Ketentuan lebih lanjut mengenai data cara pengiriman limbah $\mathrm{B}_{3} \mathrm{ke}$ luar negeri ditetapkan oleh Menteri Perdagangan, setelah mendapat pertimbangan Badan Pengendalian Dampak Lingkungan.

\section{PENANDAAN LIMBAH B3}

langanan, penyimpanan, dan pengangkutan limbah B3 harus dilakukan den cara yang aman bagi pekerja, masyarakat, dan lingkungan. Faktor penting g berhubungan dengan keamanan ini adalah penandaan pada kemasan dan daraan yang digunakan untuk mengangkut limbah B3.

\section{IDENTIFIKASI PENANDAAN}

Penandaan berguna sebagai petunjuk adanya limbah B3 dalam suatu kemasan atau kendaraan pengangkut. Penandaan menjadi sumber informasi tentang jenis dan karakteristik limbah B3 bagi orang yang menangani, menyimpan, dan mengangkut limbah B3 tersebut dan merupakan hal yang sangat penting bila terjadi keadaan darurat.

Tanda yang digunakan untuk penandaan ada dua jenis, yaitu label dan simbul. Simbul dipasang pada kemasan dan kendaraan pengangkut. Label dipasang pada kemasan. Operator yang bekerja pada tempat penyimpanan atau pengangkutan limbah B3 harus memiliki dokumen yang berhubungan dengan penandaan.

\section{LABEL}

Label berfungsi untuk memberikan informasi tentang : Nama dan Alamat Penghasil, Nomor Penghasil, Tanggal Pengemasan, Kode Limbah dan Uraian Limbah (sifat, jumlah dan jenis limbah). Label harus terlihat, paling sedikit, dari dua sisi kemasan dan jangan dipasang pada bagian yang akan tertumpuk oleh kemasan atau benda lain. Label harus dipasang pada kemasan yang akan dimasukkan ke dalam kemasan yang lebih besar.

Label berbentuk bujur sangkar dengan panjang sisi minimal $25 \mathrm{~cm}$, tahan terhadap perlakuan atau bahan kimia yang mengenainya. Label tidak boleh terlepas dari kemasan sebelum kemasan tersebut dibersihkan dari limbah B3 yang ada didalamnya harus dipasang label "KOSONG". Untuk menghindari terjadinya tumpahan atau kebocoran limbah B3 cair atau sludge diperhatikan cara meletakkan kemasaan limbah B3 cair atau kemasan sludge B3.

\section{SIMBOL}

Simbol berfungsi untuk memberikan informasi ientang karakteristik limbah B3.

Ada dua maacam simbul :

1. Simbol yang dipasang pada kendaraan pengangkut

Majalah Barang Kulit, Karet dan Plastik
2. Simbol yang dipasang pada kemasan

Simbol berbentui. bujur sangkar. Panjang sisi simbul untuk kemasan minimal $10 \mathrm{~cm}$ dan untuk kendaraan pengangkut minimal $25 \mathrm{~cm}$. Pada keempat s. bujur sangkar _. batas simbul berupa garis sejajar dengan sisi-sisi bujur sangkar sehingg. membentuk bujur sangkar dalam. Warna batas sama dengan warna gambur simbul. Simbul untuk kendaraan pengangkut terbuat dari bahan plastik atau logam yang tahan terhadap kondisi yang mungkin menimpanya. Simbul untuk kemasan harus dapat dilekatkan pada kemasan dan tahan terhadap bahan kimia.

Simbol harus terlihat jelas dari kedua sisi maupun dari bagian belakang kendaraan pengangkut. Simbul untuk kemasan dipasang pada kedua sisinya; tidak boleh dipasang pada bagian bawah atau atas kemasan tersebut.

Jika limbah yang akan dikemas atau diangkut merupakan limbah B3 campuran (mixed load) harus digunakan simbul khusus untuk limbah B3 campuran. Pengangkut berkewajiban memberikan informasi mengenai karakteristik limbah campuran ini kepada pengemudi. Simbul tidak boleh dilepas sebelum kendaraan dibersihkan dari limbah B3.

Badan Pengendalian Dampak Lingkungan menetapkan simbol dan label untuk setiap jenis limbah B3.

\section{TANGGUNG JAWAB}

Penghasil dan pengangkut limbah B3 wajib memasang simbul dan label yang memenuhi syarat pada kemasan dan kendaraan pengangkut. Jika simbul dan/ atau label rusak pada waktu penyimpanan atau pengangkutan, maka pihak yang bertanggung jawab terhadap limbah B3 pada saat itu, harus mengganti dengan label dan/atau simbul yang baru. Pemasang simbul harus yakin bahwa simbul dan label yang dipasang pada kemasan dan kendaraan sesuai dengan karakteristik dan jenis limbah B3 nya. Karyawan perlu mendapat pelatian tentang simbul dan label agar dapat mengindeantifikasi limbah dan mengatasi jika terjadi keadaan darurat.

Untuk menghindari timbulnya dampak negatif yang tidak diinginkan sebagai akibat dipergunakannya B3 oleh perusahaan industri, maka perusahaan industri yang bersangkutan bertanggung jawab sepenuhnya terhadap pengelolaan B3 mulai dari pengadaan dipabrik, penyimpanan, pengolahan, pengemasan dan pengangkutan sampai distributor. 
BAPEDAL, Peraturan Pemerintah Republik Indonesia No. 19 Tahun 1994 Tentang Pengelolaan Limbah Bahan Berbahaya dan Beracun.

Departemen Perindustrian, Pengamanan Bahan Berbahaya dan Beracun di Perusahaan Industri, 1985.

Himpunan Peraturan di Lingkungan Hidup, 1991, EKO JAYA JAKARTA.
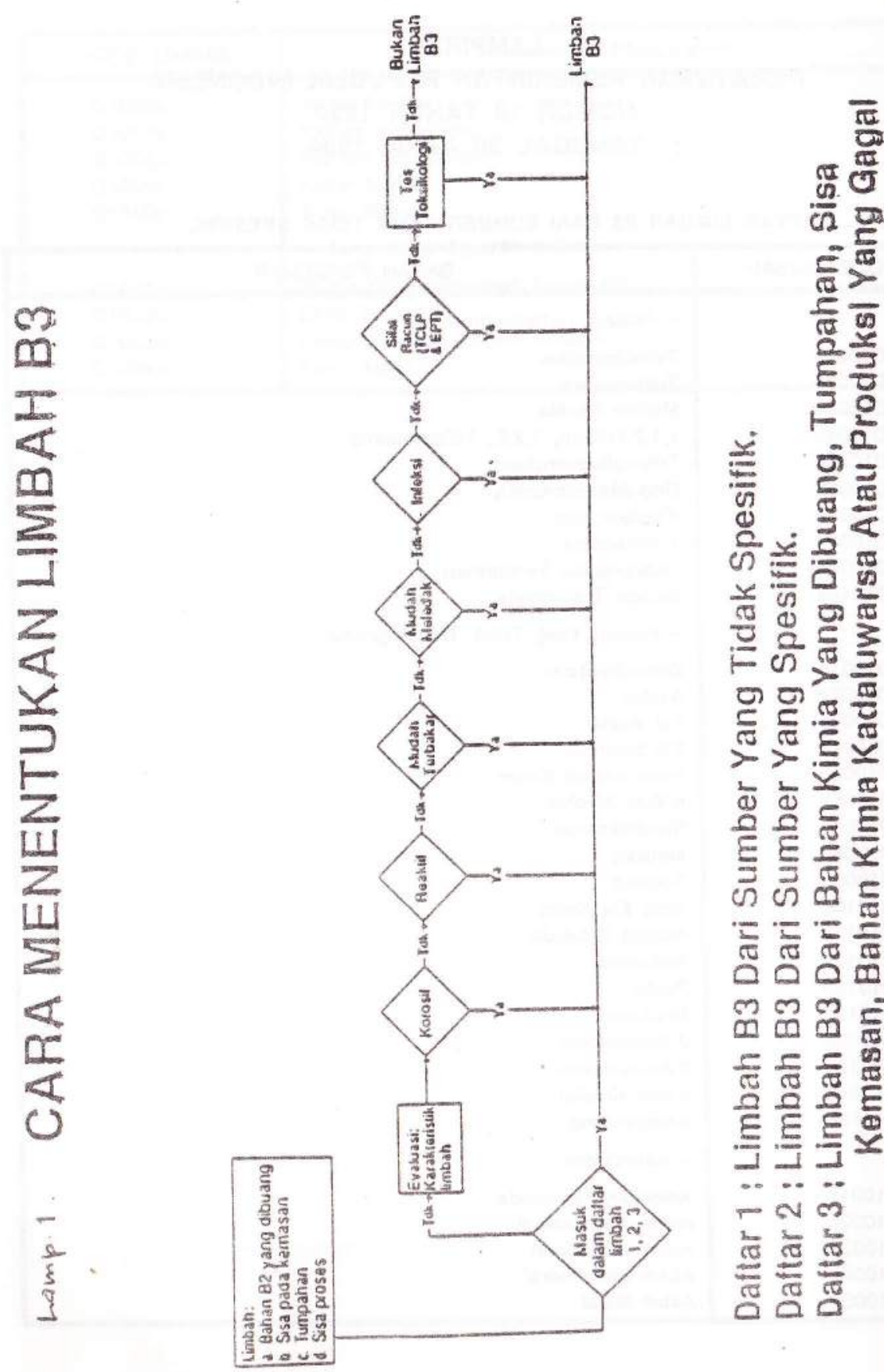
LAMPIRAN

PERATURAN PEMERINTAH REPUBLIK INDONESIA

NOMOR 19 TAHUN 1998

TANGGAL 30 APRIL 1994

EL 1. DAFTAR LIMBAM B3 DARI SUMBER YANG TIDAK SPESIFIK.

\begin{tabular}{|c|c|}
\hline KODE LUMBAAH & QAHAN PENCEMAR \\
\hline & - Pelarut Torhalogenasi \\
\hline 01001 a & Tetrakioroetilen \\
\hline $01002 a$ & Trikloroesiten. \\
\hline $01003 a$ & Metilen Klorida \\
\hline Di004s & 1,1,2-Triblore, 1,2,2. Tritluorcetana \\
\hline Dioosa & Tritkorothoromelana \\
\hline D $1006 a$ & Ono-diktorobenzena \\
\hline Di007a & Klorobenzena \\
\hline D1008a & Trikloroetana \\
\hline $01009 \mathrm{a}$ & Fluorokarbon Terkiorinasi \\
\hline Droroa & Karbon Tetrakborida \\
\hline & - Pelarut Yang Tidak Terhalogenasi \\
\hline D10010 & Dimetilbenzens \\
\hline 010020 & Asoton: \\
\hline $01003 b$ & Etd Asotat \\
\hline D100Ab & Ettil Benzens \\
\hline Dioosb & Mein isoburid Keton \\
\hline Dio06b & n-Autd Alkohol \\
\hline Di007b & Sikloheksanon \\
\hline D1008b & $\begin{array}{l}\text { Alelanol } \\
\text { Toluen }\end{array}$ \\
\hline D10090 & $\begin{array}{l}\text { Toluens } \\
\text { Metl Eul Keton }\end{array}$ \\
\hline Droiob & $\begin{array}{l}\text { Meth Ent Keton } \\
\text { Karbon Disulfida }\end{array}$ \\
\hline Dioilo & $\begin{array}{l}\text { Karbon Disulfida } \\
\text { isobutianol }\end{array}$ \\
\hline 010120 & $\begin{array}{l}\text { isobutanol } \\
\text { Pindin }\end{array}$ \\
\hline $\begin{array}{l}\text { Dio13b } \\
\text { D10:4b }\end{array}$ & $\begin{array}{l}\text { Pindin } \\
\text { Benzers }\end{array}$ \\
\hline $\begin{array}{l}\text { D1014b } \\
01015 b\end{array}$ & $\begin{array}{l}\text { Benzens } \\
\text { 2-Eroksietanol }\end{array}$ \\
\hline $\begin{array}{l}010150 \\
010160\end{array}$ & $\begin{array}{l}\text { 2-Eroksietanol } \\
\text { 2-Nutopropana }\end{array}$ \\
\hline $\begin{array}{l}01016 b \\
010170\end{array}$ & $\begin{array}{l}\text { 2-Nutopropana } \\
\text { Asam Kresilat }\end{array}$ \\
\hline $\begin{array}{l}01017 b \\
010180\end{array}$ & Nutrobenzana \\
\hline & - Asam:Bass \\
\hline Dioote & Amonium Midroksicia \\
\hline $01002 c$ & Asam Hidrobiomat \\
\hline $01003 c$ & Asam Hidroklorat \\
\hline D1004c & Asam Hidrefluorat \\
\hline $0: 005 e$ & Asam Nitrat \\
\hline
\end{tabular}

\begin{tabular}{|c|c|}
\hline KODE LIMBAH & BAHAN PENCEMAR \\
\hline $\begin{array}{l}\text { D1006c } \\
\text { D1007c } \\
01008 c \\
\text { D1009c } \\
\text { D1010c } \\
\text { D1001u } \\
\text { D1002d } \\
\text { D1003d } \\
\text { D1004d }\end{array}$ & $\begin{array}{l}\text { Asam Fostat } \\
\text { Kalium Hidroksida } \\
\text { Natrium Hidroksida } \\
\text { Asnm Sullat } \\
\text { Asam Klorida } \\
\text { - Yang Tidak Spesitik I.ainnye } \\
\text { PCB's (Polychlorinaled biphenyls) } \\
\text { Lead Sciap } \\
\text { Limban Minyak Diesel Industil } \\
\text { Fivet Asbes }\end{array}$ \\
\hline
\end{tabular}


2. DAFTAR LIMBAH B3 DARI SUMBER YANG SPESIFIK.

\begin{tabular}{|c|c|c|}
\hline Limbah & Jenis Industrikegiatan & Uraian Limbah \\
\hline 201 & Pupuk & - Kasalis \\
\hline 202 & Pestusida & $\begin{array}{l}\text { - Sludge pengolahan limbah caik } \\
\text { - Tong dan macam-macam alat yang } \\
\text { digunakan uotuk formulasi } \\
\text { - Buangan produk yang lidak memenuhi } \\
\text { spesitikasi }\end{array}$ \\
\hline 203 & Proses kloro alkali & $\begin{array}{l}\text { - Sludge pengolahan limbah cair (proses } \\
\text { merkuri) } \\
\text { - Puritikasi garam }\end{array}$ \\
\hline 204 & $\begin{array}{l}\text { Adesil (UF. PF. MF, } \\
\text { lain-lain) }\end{array}$ & $\begin{array}{l}\text { - Buangan produk yang lidak memenuhi } \\
\text { spesitikasi } \\
\text { - Katalis }\end{array}$ \\
\hline 205 & $\begin{array}{l}\text { Industri Polimer (PVC. } \\
\text { PVA, lain-tain) }\end{array}$ & $\begin{array}{l}\text { - Monomer yang tidak bereaksi } \\
\text { - Katalis }\end{array}$ \\
\hline 206 & Petrokimia & $\begin{array}{l}\text { - Sludge } \\
\text { - Katalis } \\
\text { - Tar }\end{array}$ \\
\hline 0207 & Pengawetan kayu & - Sludgo \\
\hline 0208 & $\begin{array}{l}\text { Peleburan/pengolahan } \\
\text { besi can baja }\end{array}$ & - Debu tungku pembakat \\
\hline 0209 & $\begin{array}{l}\text { Operasi penyempurnaan } \\
\text { baja }\end{array}$ & $\begin{array}{l}\text { - Limban asam } \\
\text { - Lumbah basa } \\
\text { - Limban sianida } \\
\text { - Sludge logan betal }\end{array}$ \\
\hline D210 & Peleburan tumbal bekas & $\begin{array}{l}\text { - Sludge } \\
\text { - Debu } \\
\text { - Slag }\end{array}$ \\
\hline 0211 & $\begin{array}{l}\text { Industr lembiga } \\
\text { - Peleburan dinn } \\
\text { pernurnian } \\
\text { - Tungku olektrik }\end{array}$ & $\begin{array}{l}\text { - Detu lungku pernuakat } \\
\text { - Sudge } \\
\text { - Pelarut bekas }\end{array}$ \\
\hline 0212 & Pabrik tunta & $\begin{array}{l}\text { - Shucge } \\
\text { - Petarut bekas }\end{array}$ \\
\hline $\mathrm{D} 213$ & $\begin{array}{l}\text { Tekstil } \\
\text { - Finushing } \\
\text { - Pencelupan }\end{array}$ & - Sludge yang mengandung logam betat \\
\hline 0214 & Perakkan Kendaraan & $\begin{array}{l}\text { - Studge } \\
\text { - Pelarut organik dan anorganik bekas }\end{array}$ \\
\hline
\end{tabular}

\begin{tabular}{|c|c|c|c|c|}
\hline Kode Limbah & Jenis Industrikegiatan & \multicolumn{3}{|c|}{ Uraian Limbah } \\
\hline $\mathrm{D} 215$ & $\begin{array}{l}\text { Elektrogalvani dan } \\
\text { elektroplating }\end{array}$ & $\begin{array}{l}\text { - Sludge } \\
\text { - Larulan olekriolit }\end{array}$ & bokas & \\
\hline 0216 & Industri cat & $\begin{array}{l}\text { - Sludoe } \\
\text { - Pelarul bekns }\end{array}$ & & \\
\hline D217 & Balerai kering & $\begin{array}{l}\text { - Sludge } \\
\text { - Pnsto (Mix) } \\
\text { - Buangan produk } \\
\text { sposilikasi }\end{array}$ & yang tidnk , & momenum \\
\hline 0218 & Aki & $\begin{array}{l}\text { - Sludge } \\
\text { - Dobu }\end{array}$ & & \\
\hline D219 & $\begin{array}{l}\text { Perokitan dan komponen } \\
\text { olektionika }\end{array}$ & $\begin{array}{l}\text { - Sludge } \\
\text { - Pelatut bekas }\end{array}$ & & \\
\hline $\mathrm{D} 220$ & $\begin{array}{l}\text { Exsplorasi minyak dan } \\
\text { gas bumi } \\
\text { - Eksplorasi dan produksi } \\
\text { - Pemelhinnan lasilins } \\
\text { pioduksi }\end{array}$ & $\begin{array}{l}\text { - Emulsi minyak sis } \\
\text { - Lumpur bot } \\
\text { - Shidge }\end{array}$ & sisa & \\
\hline $\mathrm{D} 221$ & $\begin{array}{l}\text { Kilang minyak } \\
\text { - Dissolved Ait Floatation } \\
\text { - Heat exchanget } \\
\text { - Dasat tangkt }\end{array}$ & $\begin{array}{l}\text { - Sludge } \\
\text { - Kaialis } \\
\text { - Padaian dan emu } \\
\text { - Karbon akut }\end{array}$ & nu!si minyak & \\
\hline $\mathrm{D} 222$ & Penambangan & $\begin{array}{l}\text { - Sludge logam be } \\
\text { - Pelarut }\end{array}$ & erat & \\
\hline $\mathrm{D} 223$ & PLTU & $\begin{array}{l}\text { - Fly ash } \\
\text { - Bonom ash }\end{array}$ & & \\
\hline D224 & $\begin{array}{l}\text { Penyamakan dan } \\
\text { pengolahan kuin }\end{array}$ & $\begin{array}{l}\text { - Sludge } \\
\text { - Pelarul bekas }\end{array}$ & $\cdots$ & \\
\hline D225 & Zat warna & $\begin{array}{l}\text { - Sludge } \\
\text { - Pelarut bekas }\end{array}$ & & \\
\hline $\mathrm{D} 226$ & Industri obat & $\begin{array}{l}\text { - Sludge } \\
\text { - Pelarut bekas } \\
\text { - Buangan produk } \\
\text { spesilikasi }\end{array}$ & yang tidak $n$ & memenuhi \\
\hline $\mathrm{D} 227$ & $\begin{array}{l}\text { Rumah sakin dan } \\
\text { laboratcriumnya }\end{array}$ & $\begin{array}{l}\text { - Antibiotik kadaluw } \\
\text { - Peralatan modix } \\
\text { - Limbah infeksi } \\
\text { - Kemasan obai-ob }\end{array}$ & yang terkont: & ntaminasi \\
\hline $\mathrm{D} 228$ & $\begin{array}{l}\text { Laboratorium risel dan } \\
\text { komersial }\end{array}$ & $\begin{array}{l}\text { - Pelarut bekas } \\
\text { - Bahan kimia kad: } \\
\text { - Sisa contoh }\end{array}$ & daluwarsa & 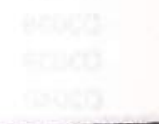 \\
\hline
\end{tabular}


3E1 DAFTAR UIGAH B3 DARI BAHAN KIMIA KADALUWAASA, TUMPAHAN, SISA KEMASAN AYAU BUANGAN PRODUK YANG TIDAK MEMENUHI SPESIFIKASI

\begin{tabular}{|c|c|c|c|}
\hline KODE LIMBAH & \multicolumn{3}{|c|}{ BAHAN PENCEMAR } \\
\hline D3001 & Aseraldehida & & \\
\hline 03002 & Asotamida & & \\
\hline 03003 & Asam Asetat, Gatar & m-garan dan Ester-esternya & \\
\hline D3004 & Asaton & & \\
\hline D3005 & Aselonitris & & \\
\hline 03006 & Asetiakiorida & & \\
\hline 03007 & Alcrotein & & \\
\hline 03008 & Alezilamida & & \\
\hline 03009 & Akriloniatit & & \\
\hline 03010 & Aidrin & 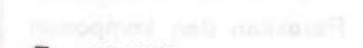 & \\
\hline D3011 & Äumunium Alkil da & in Turunannya & \\
\hline D3012 & Alumunium fostat & & \\
\hline 03013 & Amonium Pikrat & & \\
\hline 03014 & Amonium Variadat & & \\
\hline 03015 & Anitina & & \\
\hline 03016 & Aisen & & \\
\hline 03017 & Arsen Oksida. Pent & 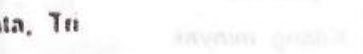 & \\
\hline 03018 & Dietarsin & & \\
\hline 03019 & Barium & & \\
\hline 03020 & Chromated Copper & Arsenal & \\
\hline 03021 & Benzena & & \\
\hline 03022 & Kionobenzens & & \\
\hline 03023 & 1.3 Dusosianaitomet & wh ben:ena & \\
\hline D3024 & Detdbenzena & & \\
\hline 03025 & Hetsahidicubonizena & & \\
\hline 03026 & Benzenasultonat $A s$ & $\sin$ Klorda & \\
\hline 03027 & Benzenasultonal Kio & grka & \\
\hline 0.3028 & Berstum dan Turun & nanuy & \\
\hline 03029 & Bus(klorometil)eler & & \\
\hline 03030 & Bromutorn & & \\
\hline 0.2031 & 1.1.2.3.4.4 heksaikb & ro.1.3. Butadiena & \\
\hline 03032 & n.Butd Akrohol & & \\
\hline 03033 & Bulena & & \\
\hline $030: 34$ & Butdaklehocia & & \\
\hline 0.3035 & Kavmiurn & & \\
\hline 03036 & Katsium Kinunat & & \\
\hline 0.037 & Amoniacal Çopper & Arsenal & \\
\hline 03038 & Dikbro Karbonal & & \\
\hline 03039 & Karbon Disullinis & & \\
\hline 03040 & Karbon Tetraklorida & & \\
\hline
\end{tabular}

\begin{tabular}{|c|c|}
\hline KODE UMBВAH & BAHAN PENCEMAR \\
\hline 03041 & Kloronsetaldehida \\
\hline 03042 & Morodana. Isomer Alta dan Beis \\
\hline D 3043 & Kloroe:ana (Et: Kuoridn) \\
\hline D3044 & Kloroelena Nind Klorida) \\
\hline ososs & Klor citibnomometana \\
\hline D.2046 & Klosolorm \\
\hline D3047 & p. Kioromminsa \\
\hline 03048 & 2. Klosment Vint Esert \\
\hline 03049 & Koromment melli eler \\
\hline D3050 & Asain Keomat, dan Garam gasam Kalsummya \\
\hline 03051 & Kiøanum \\
\hline D3052 & Sianda dan senyswa-senymwanya \\
\hline 03053 & kimsnt \\
\hline D305- & Curnone \\
\hline D3055 & Sikbohehsinas \\
\hline D.3056 & 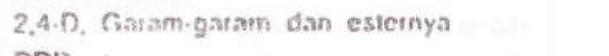 \\
\hline D3057 & DDD \\
\hline D305B & Dor \\
\hline D3059 & 1.2.Ditbrobenzens \\
\hline D3060 & P.3. Onderobenzens \\
\hline 03051 & 1.2. Dibneretans \\
\hline D3062 & 1.1. Diblorostana \\
\hline D3063 & 1.2.Dakloropropana \\
\hline D3064 & 1,2-Dikloropiopena \\
\hline D3065 & Dieidrin \\
\hline D3066 & Dimeit Fiaiat \\
\hline D3067 & Dimetal Sutial, \\
\hline D3068 & 2,4-Dinurotoluena \\
\hline 03059 & 2.6-Dinitrololuena \\
\hline 03070 & Endrin Jan Senyawa Metabolitnya \\
\hline D30?1 & Epiklorohidrin \\
\hline D3072. & 2-Etoksi Etanol \\
\hline D3073 & 1.Fenil Etanon \\
\hline D 3074 & Etil Akritat \\
\hline D3075 & Etd Asetal \\
\hline 03076 & Elibenzena \\
\hline 03077 & Eil Karbamal (Uretan) \\
\hline D 3078 & Eur Eier \\
\hline D3079 & Asam Eliten Bisditiokarbamat dan iurunannya \\
\hline D3080 & Elilen Dibromida \\
\hline 03081 & Etilen Dikiorida \\
\hline D3082 & Erilen Glikol (Monoetil Eler) \\
\hline D3083 & Etilen Oksida (Oksirana) \\
\hline
\end{tabular}




\begin{tabular}{|c|c|}
\hline KOOE LIMBAH & BAHAN PENCEMAA \\
\hline 03084 & Fluorin \\
\hline D3085 & Fivoroaseiamida \\
\hline 03086 & Asam Fluoroaselal dan garam sodiumnya \\
\hline D3087 & Formakdehida \\
\hline 03088 & Asam Formiat \\
\hline D3089 & Furan \\
\hline 03090 & Hepiaktor \\
\hline 03091 & Heksakkrobenzena \\
\hline D3092 & Heksaklorobuladiena \\
\hline 03093 & Heksakloroelana \\
\hline 030948 & Hidrogen Sianida \\
\hline D3095 & Hidrazina \\
\hline 03094 & Asam Fosiat \\
\hline 03095 & Âsam Floutal \\
\hline 03096 & Asam Fluorida \\
\hline 03097 & Asam Suthda \\
\hline 03098 & Hidroksibenzena (Fenol) \\
\hline D3099 & Hodroksilohen (Kresol) \\
\hline D3100 & Isobuth Alkohol \\
\hline D3101 & Isobutanol \\
\hline 03102 & Tumhal Asetai \\
\hline 03103 & Tmoal Kromat \\
\hline 03104 & Tunbat Nirat \\
\hline D3105 & Tumbal Onsuda \\
\hline 03106 & Tumbal Fostat \\
\hline 03107 & Landana \\
\hline D3108 & Maleat Anhustioda \\
\hline D3109 & Baleat Hudrazida \\
\hline 03110 & Metkuri dan senyawa-senyawanya \\
\hline 03111 & Hets Heorationa \\
\hline D3112 & Reetd Paration \\
\hline $031: 3$ & Tetrakbornetana \\
\hline D3114 & Tribiomonetana \\
\hline 03115 & Thrbaromelani \\
\hline 03116 & Tablorolivoroinetara \\
\hline 03117 & Metamal \\
\hline 03118 & Metokstklor \\
\hline D3819 & Mets Aikonol \\
\hline D3120 & Siletid Buomida \\
\hline D3121 & hieth Klorida \\
\hline 03122 & Metd Ktorotorn \\
\hline 03123 & Metulen Bramida \\
\hline 0312.4 & Meftal Isobuta Keton \\
\hline
\end{tabular}

\begin{tabular}{|c|c|}
\hline KODE LIMBAH & BAHAN PENCELAR \\
\hline D3125 & Metil Eul Keion \\
\hline 03126 & Metil Ell Kelon Peroksida \\
\hline D3127 & Motil Benzina (Tolven) \\
\hline 03128 & Meid lodión \\
\hline 03129 & Nafialeno \\
\hline D3130 & Nitral Oksida \\
\hline D3131 & Ninobenzena \\
\hline D3132 & Nitrogliserin \\
\hline D3133 & Oksirand \\
\hline $03: 34$ & Poration \\
\hline D3135 & Parnidehuda \\
\hline D3136 & Pentahlorobenzens \\
\hline D3137 & Pontakbroetann \\
\hline$D 3938$ & Pentakioronitrobenzens \\
\hline D3:39 & Pentakiorolenol \\
\hline 03140 & Pentakloroetilen \\
\hline D3141 & Fenol \\
\hline $\mathrm{D} 3142$ & Fenil Toures \\
\hline$D 3143$ & Fosgen \\
\hline D3144 & Fosin \\
\hline D3145 & Asiam Fostat \\
\hline D3146 & Fostor Sultida \\
\hline D3147 & Fosier Pentasultida \\
\hline D3148 & Fiatal Anhidrida \\
\hline D3149 & 1.Bromo.2.Propanon \\
\hline D3150 & 2-Nitropropana \\
\hline D3151 & n-Propilamina \\
\hline D3152 & Propilen Diklorida \\
\hline 03153 & Pirena \\
\hline 03154 & Piredena \\
\hline D3155 & Selenium \\
\hline D3156 & Selenium Dioksida \\
\hline D3157 & Selenium Sulfida \\
\hline D3158 & Perak Sianida \\
\hline D3159 & 2.4.5-TP (silvex) \\
\hline 03160 & Natrium Azide \\
\hline D3161 & Striknidin-10-satu dan Garam-garamnya \\
\hline D3162 & Asam Sullat, Dimetil Ester Sultat \\
\hline D3163 & Sullut Fosin \\
\hline D3164 & $2.4 .5-T$ \\
\hline 03165 & 1.2.4,5. Tetrakbrobenzena \\
\hline 03166 & 1,1,1.2-Tetrakloroetana \\
\hline D3167 & 1,1,2,2-Tetrakioroetana \\
\hline
\end{tabular}




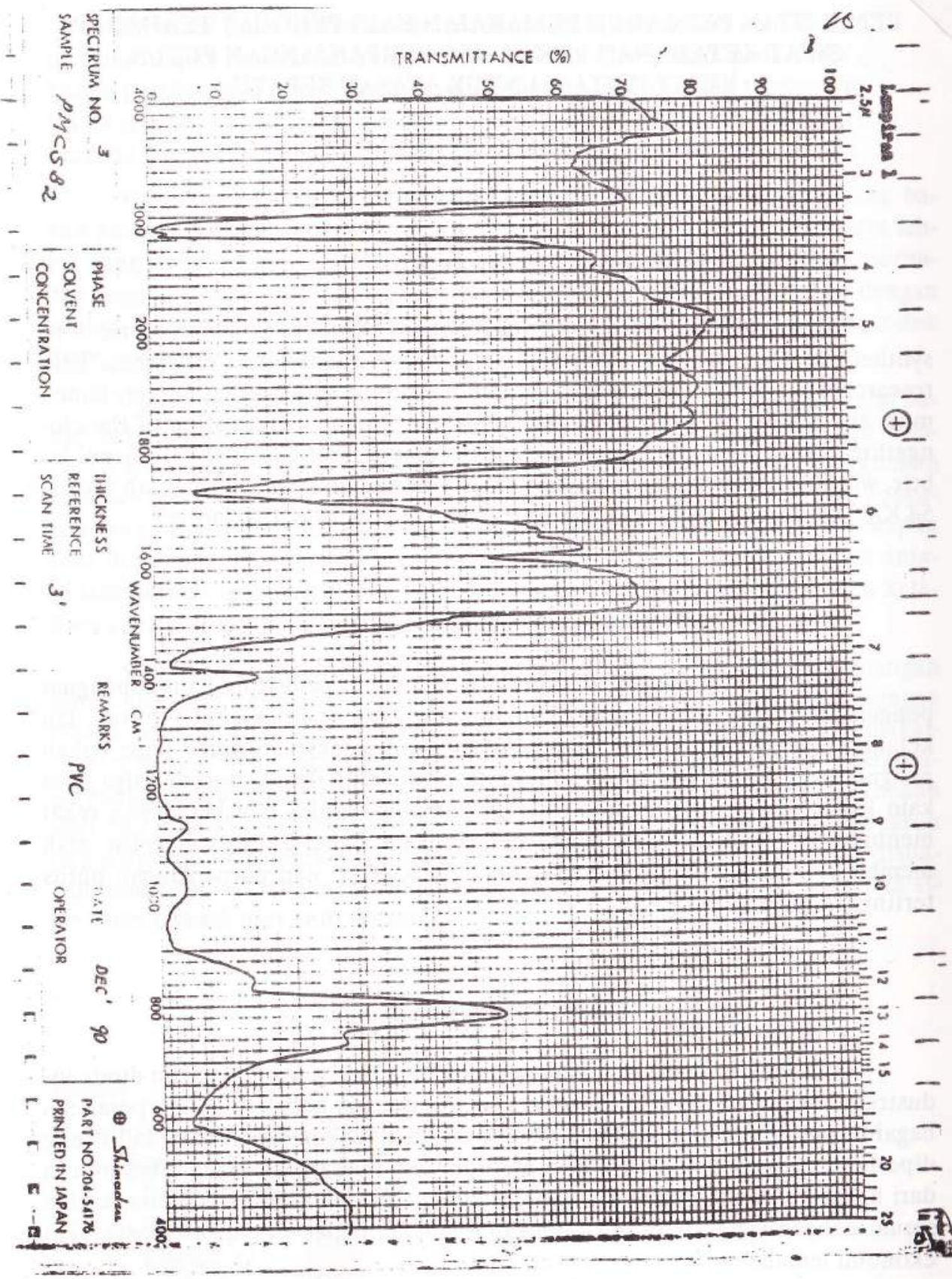

Salinan sesuai aslinya EKRETARIAT KABINET RI Kepala Biro Hukum dan Perundang-undangan u.b. Kepala Bagian Penelitian

Perundang-undangan I

ambock V. Nahattands, S.H.

PRESIDEN REPUBLIK INDONFSIA

nd

SOEHARTO
2.3.4.6- Tetraktorolenol

4,5. Triktorotono

4.6-Tnkiorolenol

anadium Oksida

nadium Pentaokside

Wartsuin

Wemotdienzena

Somg Fosin $(C>10 \%)$ 